\title{
Effects of salt stress on physiological and biochemical responses of three maize genotypes at the early seedling stage
}

\author{
Ali DOĞRU ${ }^{1,2}$
}

Effects of salt stress on physiological and biochemical responses of three maize genotypes at the early seedling stage

Abstract: Salt stress is one of the major global problems for crop productivity in the arid and semi-arid regions of the world. In this study, variations in some physiological parameters, water relations, and antioxidant systems under salinity $(300 \mathrm{mM} \mathrm{NaCl})$ among three maize (Zea mays L.) genotypes ('P3167', '32K61', and 'Bora') were investigated. Our result indicated that shoot growth is more sensitive to salinity as compared to root growth. Salt stress led to physiological drought in all maize genotypes as indicated by the significant decrease in relative water content and increase in water deficit index. Salt stress increased SOD activity in all genotypes showing an efficient formation and detoxification of superoxide radical. The constant level of oxidative markers (MDA and $\mathrm{H}_{2} \mathrm{O}_{2}$ ) and the increased level of the reduced ascorbate and phenolic may indicate that non-enzymatic antioxidants are responsible for the elimination of oxidative stress. Changes in ascorbate peroxidase and glutathione reductase activities under salinity demonstrated a functional failure in the ascorbate-glutathione cycle, especially in 'P3167' and '32K61'. Based on the presented results we may conclude that the genotype 'Bora' is tolerant to salinity while 'P3167' and '32K61' are sensitive.

Key words: antioxidant system; oxidative stress; phenolics; salinity; soluble sugars
Received November 12, 2020; accepted December 25, 2020. Delo je prispelo 12. novembra 2020, sprejeto 25. decebra 2020.

Učinek solnega stresa na fiziološki in biokemični odziv treh genotipov koruze v zgodnji razvojni stopnji semenke

Izvleček: Solni stres je eden največjih globalnih problemov za uspevanje gojenih rastlin $\mathrm{v}$ sušnih in polsušnih območjih sveta. $\mathrm{V}$ raziskavi so bili preučevani nekateri fiziološki parametri, vodni režim in antioksidacijski system v razmerah slanosti $(300 \mathrm{mM} \mathrm{NaCl})$ pri treh genotipih koruze (Zea mays L.; 'P3167', '32K61', in 'Bora'). Izsledki so pokazali, da je rast poganjka bolj občutljiva na slanost $\mathrm{v}$ primerjavi $\mathrm{z}$ rastjo korenin. Solni stres je povzročil fiziološko sušo pri vseh genotipih koruze, ki se je izražala kot značilen upad v relativni vsebnosti vode in povečanju indeksa vodnega deficita. Solni stres je povečal aktivnost SOD pri vseh genotipih, kar kaže na učinkovito razstrupljanje superoksidnega radikala. Stalna raven vsebnosti označevalcev oksidacije ( $\mathrm{MDA}$ in $\mathrm{H}_{2} \mathrm{O}_{2}$ ) in povečana vsebnost reduciranega askorbata ter fenolov lahko nakazujejo, da so neencimski antioksidanti odgovorni za odpravo oksidacijskega stresa. Spremembe v aktivnosti askorbat peroksidaze in glutation reduktaze $\mathrm{v}$ razmerah slanosti so pokazale funkcionalni zlom askorbat-glutationskega cikla, še posebej pri 'P3167' in '32K61'. Na osnovi predstavljenih izsledkov lahko zaključimo, da je genotip 'Bora' toleranten na slanost, medtem ko sta 'P3167' in '32K61' občutljiva.

Ključne besede: antioksidacijski sistem; oksidativni stres; fenoli; slanost; topni sladkorji

1 Sakarya University Faculty of Arts and Science Department of Biology, Esentepe, Sakarya, Turkey

2 Corresponding author, e-mail: adogru@sakarya.edu.tr 


\section{INTRODUCTION}

Salt stress is one of the most prominent agricultural problems for plant productivity in the arid and semiarid soils in the world. High salinity in soils is responsible for the reduced yield for several crops. Munns and Tester (2008) reported that 45 million hectares of land had been affected by salinity worldwide, and 1.5 million hectares are taken out of cultivation each year due to over-accumulation of salts in the soil. Salinity leads to reductions in several metabolic processes associated with growth, development, and crop productivity (Fayez and Bazaid, 2014). Seed germination, for example, is inhibited by salt stress in several plant species (Ahammed et al., 2018; Gu et al., 2018; Orlovsky et al., 2016; Wilayasinghe et al., 2019; Khayamim et al., 2014). In black gram and mung bean plants, it was observed that salt stress affected water relations as well (Hasan et al., 2019). It was also reported that salt stress reduced root and shoot growth in barley plants depending on genotypes and salt concentration (Doğru and Yılmaz Kaçar, 2019). In plants under optimal growth conditions, the balance between reactive oxygen species (ROS) formation and detoxification is tightly controlled by the antioxidant system (Hameed et al., 2011). However, salt stress may cause the accelerated production of reactive oxygen species (ROS) and oxidative stress in the plant cells as a result of higher leakage of electrons toward $\mathrm{O}_{2}$ during photosynthetic and respiratory electron transport reactions (Asada, 2006). Mittler (2002) has indicated that much of the damage on plants under salt stress is linked to oxidative stress at the cellular level. Plants that have higher antioxidant enzyme activities were considered salt-tolerant (Gapinska et al., 2008). Higher plants have developed several adaptive mechanisms to cope with oxidative stress under saline conditions such as the increased synthesis of osmoprotectants. Proline and soluble sugars, for example, accumulate in plant tissues and contribute to osmoregulation, structural protection of some biomolecules and membranes, and detoxification of ROS in plants under salt stress (Hare et al., 1998; Ashraf and Foolad, 2007; Abdelkader et al., 2019). Proline may also serve as an organic nitrogen reserve that could be utilized during stress recovery (Sairam and Tyagi, 2004). Among phenolic compounds anthocyanins have been well known to accumulate under salt stress and play an important role in scavenging ROS in plant tissues as well (Petridis et al., 2012; Chunthaburee et al., 2016).

Breeding for salt tolerance in crop plants has usually been limited because of the lack of reliable traits for selection (Ylldirım et al., 2008). Salt tolerance is very complex because multiple genes are involved. In this case, it seems that the most effective way to overcome the salinity problem may be the introduction of salt-tolerant crops. Therefore, this experiment was conducted to determine some physiological and biochemical responses in three maize genotypes grown under salt stress through some growth parameters (root and shoot length), water relations (relative water content end water deficit index), photosynthetic pigment content (chlorophyll a and b), oxidative stress markers (malondialdehyde and hydrogen peroxide content) and some endogenous resistance mechanisms (anthocyanin, free proline, total phenolics, total soluble carbohydrate contents and activities of some antioxidant enzymes).

\section{MATERIAL AND METHODS}

\subsection{PLANT MATERIALS, GROWTH CONDITIONS, AND EXPERIMENTAL DESIGN}

Maize (Zea mays L.) cultivars ('P3167', '32K61', and 'Bora') were grown in a growth chamber in plastic pots (14 x $14 \mathrm{~cm}$; upper diameter $\times$ height) containing Hoagland nutrient solution. The average temperature for day/night was $25 / 18{ }^{\circ} \mathrm{C}$ respectively, relative humidity was $40-50 \%$, the photoperiod for the day/night cycle was $16 / 8 \mathrm{~h}$ respectively, and the maximum photosynthetically active radiation was about $200 \mu \mathrm{mol} \mathrm{m}^{-2} \mathrm{~s}^{-1}$. After 20 days of growth, plants were divided into two groups. The first group of plants were control (no salt treatment) and watered with Hoagland nutrient solution until the end of the study. In the second group of plants, salt stress was induced by applying $300 \mathrm{mM} \mathrm{NaCl}$. For every individual genotype, we had 20 pots each of which contains 4 plants per treatment. The seedlings were harvested after 5 days of application and leaves are kept at $-80^{\circ} \mathrm{C}$ until analysis.

\subsection{DETERMINATION OF ROOT AND SHOOT LENGTH}

Measurement of root and shoot length were done with a millimetric ruler. The longest root was taken into consideration for measurement. Root and shoot length were expressed as $\mathrm{cm}_{\text {plant }}{ }^{-1}$.

\subsection{DETERMINATION OF LEAF RELATIVE WA- TER CONTENT (RWC) AND WATER DEFICIT INDEX}

Leaf samples were taken and its fresh mass was recorded immediately. The sample was then incubated in deionized water overnight and the turgid mass of the leaf 
sample was recorded. The leaf sample was oven-dried at $70{ }^{\circ} \mathrm{C}$ for $48 \mathrm{~h}$ and the dry mass of the sample was estimated. The relative water content and water deficit index were calculated according to Sairam et al. (2002).

\subsection{PHOTOSYNTHETIC PIGMENT AND ANTHO- CYANIN ANALYSIS}

Photosynthetic pigments were extracted from leaf segments in $3 \mathrm{ml} 100 \%$ acetone. The absorbance of the extracts was measured at 644.8 and $661.6 \mathrm{~nm}$ using a Shimadzu mini 1240 UV visible spectrophotometer. The concentrations of chlorophyll a and chlorophyll b were calculated according to Lichtenthaler (1987).

Total anthocyanin content was analyzed by the procedure of Mancinelli et al. (1975). Leaf sample (0.1 g) was soaked in $10 \mathrm{ml}$ of a mixture of methanol and $1 \mathrm{~N} \mathrm{HCL}$ $(85 / 15 ; \mathrm{v} / \mathrm{v})$ for $72 \mathrm{~h}$ at $4{ }^{\circ} \mathrm{C}$. The crude extracts were filtered through a $0.45 \mu \mathrm{m}$ syringe filter before measurement of total anthocyanin content at 530 and $657 \mathrm{~nm}$. The content was expressed as $\mathrm{mg} \mathrm{g}^{-1}$ fresh mass.

\subsection{MALONDIALDEHYDE (MDA) AND HYDRO- GEN PEROXIDE $\left(\mathrm{H}_{2} \mathrm{O}_{2}\right)$ ANALYSIS}

MDA and $\mathrm{H}_{2} \mathrm{O}_{2}$ content were measured by the method of Heath and Packer (1968) and Ohkawa et al. (1979), respectively. Fresh leaf material (0.1 g) was homogenized in $6 \mathrm{ml}$ of $5 \%$ TCA $\left(4^{\circ} \mathrm{C}\right)$ and centrifuged at $10000 \mathrm{~g}$ for $15 \mathrm{~min}$ and the supernatant was used in the subsequent determination. To $0.5 \mathrm{ml}$ of the supernatant were added $0.5 \mathrm{ml}$ of $0.1 \mathrm{M}$ Tris- $\mathrm{HCl}(\mathrm{pH} \mathrm{7.6)}$ and $1 \mathrm{ml}$ of TCA-TBA reagent. The mixture was warmed at $95{ }^{\circ} \mathrm{C}$ for $60 \mathrm{~min}$ and then quickly cooled in an ice bath. After centrifugation at $10000 \mathrm{~g}$ for $5 \mathrm{~min}$ to remove suspended turbidity, the absorbance of the supernatant at $532 \mathrm{~nm}$ was recorded. Non-specific absorbance at $600 \mathrm{~nm}$ was measured and subtracted from the absorbance recorded at $532 \mathrm{~nm}$. The concentration of MDA was calculated using its extinction coefficient of $155 \mathrm{mM}^{-1} \mathrm{~cm}^{-1}$. For determination of hydrogen peroxide, $0.5 \mathrm{ml}$ of $0.1 \mathrm{M}$ Tris- $\mathrm{HCl}$ (pH 7.6) and $1 \mathrm{ml}$ of $1 \mathrm{M} \mathrm{KI}$ were added to $0.5 \mathrm{ml}$ of supernatant. After $90 \mathrm{~min}$, the absorbance was measured at $390 \mathrm{~nm}$. A standard curve for hydrogen peroxide was prepared to determine hydrogen peroxide concentration in each sample.

\subsection{FREE PROLINE ANALYSIS}

Approximately $10 \mathrm{mg}$ powdered dry leaf material was extracted with $4 \mathrm{ml}$ distilled water on a hot plate at $100{ }^{\circ} \mathrm{C}$ for $10 \mathrm{~min}$ according to Bates et al. (1973). Extracts were filtered and the same procedure was repeated two times. The liquid phase of the homogenate was collected and centrifuged at $3500 \mathrm{rpm}$ for $10 \mathrm{~min}$. Two $\mathrm{ml}$ of the supernatant was reacted with $2 \mathrm{ml}$ of acid ninhydrin and $2 \mathrm{ml}$ of glacial acetic acid at $100{ }^{\circ} \mathrm{C}$ for $1 \mathrm{~h}$. The reaction mixture was mixed with $4 \mathrm{ml}$ toluene and vortexed for $20 \mathrm{~s}$. The chromophore containing toluene was separated and the absorbance of the pink upper phase was recorded at $520 \mathrm{~nm}$ against toluene blank. A standard curve for proline in the range of $0.2-1 \mu \mathrm{mol} \mathrm{ml}^{-1}$ was prepared to determine free proline concentration in each sample.

\subsection{TOTAL PHENOLIC COMPOUND ANALYSIS}

The total phenolic content of leaves was determined according to Chandler and Dodds (1983). Accordingly, $0.2 \mathrm{~g}$ leaf material was powdered in liquid nitrogen and extracted with $80 \%$ methanol. This mixture was placed in a refrigerator at $4{ }^{\circ} \mathrm{C}$ for $48 \mathrm{~h}$. homogenates were centrifuged at 4,000 rpm for $10 \mathrm{~min}$. An appropriate amount of supernatant was reacted with $50 \%$ Foline Ciocalteu Reagent (FCR) and $5 \%$ sodium carbonate and kept at room temperature at a dark place for $1 \mathrm{~h}$. The mixture was vortexed and absorbance was read at $725 \mathrm{~nm}$. The total phenolic content of the leaves was calculated by using a standard curve prepared with gallic acid.

\subsection{TOTAL SOLUBLE CARBOHYDRATE (TSC) ANALYSIS}

TSC content in leaves was measured by the phenolsulphuric method according to Dubois et al. (1956). For this purpose, leaf material $(50 \mathrm{mg})$ was oven-dried until the constant dry mass was reached. Dried leaf material was powdered in a mortar and pestle and TSS was extracted by $70 \%$ ethanol. After centrifugation of extract at $3,500 \mathrm{rpm}$ for $20 \mathrm{~min}$, a reaction mixture was prepared. This mixture consisted of $1,000 \mu \mathrm{l}$ supernatant, $300 \mu \mathrm{l}$ phenol, and 2,000 $\mu \mathrm{l}$ concentrated sulphuric acid. Absorbances of these mixtures were read at $470 \mathrm{~nm}$ and the TSC content of the leaves was calculated by a standard curve using sucrose.

\subsection{REDUCED ASCORBATE ANALYSIS}

The reduced ascorbate content was determined according to Law et al. (1983). For this purpose, leaf material $(0.2 \mathrm{~g})$ was extracted by $10 \%$ TCA. After centrifu- 
gation of extract at $10,000 \mathrm{rpm}$ for $20 \mathrm{~min}$, a reaction mixture was prepared. This mixture consisted of $400 \mu$ supernatant, $10 \%$ TCA, $5 \mathrm{M} \mathrm{NaOH}, \mathrm{NaPO}_{4}$ buffer (150 $\mathrm{mM}, \mathrm{pH} 7.4$ ), $10 \mathrm{mM}$ dithiothreitol, $0.5 \%$ N-ethylmaleimide, $44 \% \mathrm{H}_{3} \mathrm{PO}_{4}$ and $3 \% \mathrm{FeCl}_{3}$. The mixture was incubated at $37^{\circ} \mathrm{C}$ for $60 \mathrm{~min}$ and absorbances were read at $525 \mathrm{~nm}$. The reduced ascorbate content was determined by a standard curve.

\subsection{ANTIOXIDANT ENZYME ACTIVITIES}

For determination of enzyme activities, $0.3 \mathrm{~g}$ fresh leaves material from non-acclimated and cold-acclimated leaves were powdered with liquid nitrogen and suspended in a specific buffer with proper $\mathrm{pH}$ values for each enzyme. The homogenates were centrifuged at $14,000 \mathrm{rpm}$ for $20 \mathrm{~min}$ at $4{ }^{\circ} \mathrm{C}$ and resulting supernatants were used for enzyme assay. The protein concentrations of leaf crude extracts were determined according to Bradford (1976), using BSA as a standard.

Activity of superoxide dismutase (SOD; EC 1. 15. 1. 1) was determined by the method of Beyer and Fridovich (1987), based on the photoreduction of NBT (nitro blue tetrazolium). Extraction was in $1.5 \mathrm{ml}$ homogenization buffer containing $10 \mathrm{mM} \mathrm{K}_{2} \mathrm{HPO}_{4}$ buffer (pH 7.0), $2 \%$ PVP and $1 \mathrm{mM} \mathrm{Na} \mathrm{EDTA}_{2}$. The reaction mixture consisted of $100 \mathrm{mM} \mathrm{K}_{2} \mathrm{HPO}_{4}$ buffer ( $\mathrm{pH} 7.8$ ), containing $9.9 \mathrm{x}$ $10^{-3} \mathrm{M}$ methionine, $5.7 \times 10^{-5} \mathrm{M} \mathrm{NBT}, 1 \%$ triton X-100, and enzyme extract. The reaction was started by the ad- dition of $0.9 \mu \mathrm{M}$ riboflavin and the mixture was exposed to light with an intensity of $375 \mu \mathrm{mol} \mathrm{m} \mathrm{m}^{-2} \mathrm{~s}^{-1}$. After 15 min, the reaction was stopped by switching off the light, and absorbance was read at $560 \mathrm{~nm}$. SOD activity was determined by a standard graphic and expressed as unit $\mathrm{mg}^{-1}$ protein.

Activita of ascorbate peroxidase (APX; EC 1. 11. 1. 11) was determined according to Wang et al. (1991) by estimating the decreasing rate of ascorbate oxidation at $290 \mathrm{~nm}$. APX extraction was performed in $50 \mathrm{mM}$ Tris$\mathrm{HCl}$ (pH 7.2), 2 \% PVP, $1 \mathrm{mM} \mathrm{Na}$ EDTA, and $2 \mathrm{mM}$ ascorbate. The reaction mixture consisted of $50 \mathrm{mM} \mathrm{KH}$ ${ }_{2} \mathrm{PO}_{4}$ buffer ( $\mathrm{pH}$ 6.6), $2.5 \mathrm{mM}$ ascorbate, $10 \mathrm{mM} \mathrm{H}_{2} \mathrm{O}_{2}$, and enzyme, containing $100 \mu \mathrm{g}$ proteins in a final volume of $1 \mathrm{ml}$. The enzyme activity was calculated from the initial rate of the reaction using the extinction coefficient of ascorbate $\left(\mathrm{E}=2.8 \mathrm{mM} \mathrm{cm}^{-1}\right.$ at $\left.290 \mathrm{~nm}\right)$.

Activity of glutathione reductase (GR; EC 1. 6. 4. 2) was measured with the method of Sgherri et al. (1994). Extraction was in $1.5 \mathrm{ml}$ of suspension solution, containing $100 \mathrm{mM} \mathrm{KH_{2 }} \mathrm{PO}_{4}$ buffer ( $\mathrm{pH}$ 7.0), $1 \mathrm{mM} \mathrm{Na}$ EDTA, and $2 \%$ PVP. The reaction mixture (total volume of 1 $\mathrm{ml}$ ) contained $100 \mathrm{mM} \mathrm{KH}_{2} \mathrm{PO}_{4}$ buffer ( $\mathrm{pH} 7.8$ ), $2 \mathrm{mM}$ $\mathrm{Na}_{2}$ EDTA, $0.5 \mathrm{mM}$ oxidised glutathione (GSSG), $0.2 \mathrm{mM}$ $\mathrm{NADPH}$ and enzyme extract containing $100 \mu \mathrm{g}$ protein. The decrease in absorbance at $340 \mathrm{~nm}$ was recorded. The correction was made for the non-enzymatic oxidation of $\mathrm{NADPH}$ by recording the decrease at $340 \mathrm{~nm}$ without adding GSSG to the assay mixture. The enzyme activity was calculated from the initial rate of the reaction after

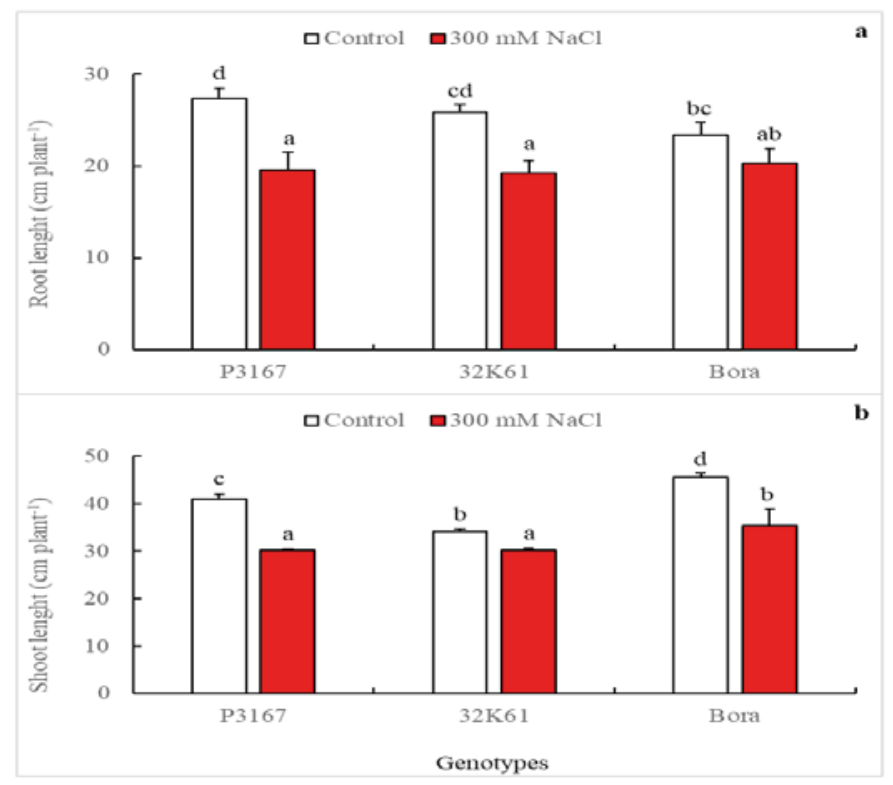

Figure 1: Effect of the salt stress on (a) root length and (b) shoot length of maize plants (Different letters mean significant differences between the treatments according to Duncan's multiple range test $(p<0.05))$ 
subtracting the non-enzymatic oxidation using the extinction coefficient of NADPH $\left(\mathrm{E}=6.2 \mathrm{mM} \mathrm{cm}^{-1}\right.$ at $\left.340 \mathrm{~nm}\right)$.

\subsection{STATISTICAL ANALYSIS}

Experiments were a randomized complete block design with three independent replicates. Analysis of variance (ANOVA) was using SPSS 20.0 statistical software for Windows. To separate significant differences between means, the Duncan test was used at ${ }^{*} p=0.05$.

\section{RESULTS}

\subsection{GROWTH}

Root growth was adversely affected by salinity in 'P3167' and '32K61' $(p<0.05)$ while it was not changed by salt stress in Bora $(P>0.05)$ (Fig. 1a). The decrease was around $28 \%, 26 \%$, and $13 \%$ in 'P3167', '32K61', and 'Bora' under $300 \mathrm{mM}$ salinity, respectively. Shoot growth declined by $27 \%$ in 'P3167', $12 \%$ in ' $32 \mathrm{~K} 61$ ', and $22 \%$ in 'Bora', and all these changes were significantly different from respective controls $(p<0.05)$ (Fig. 1b).

\subsection{WATER RELATIONS}

RWC in leaves significantly decreased in all maize genotypes by salt stress $(p<0.05)$ (Fig. $2 a)$. It was $8 \%$, $9 \%$, and $7 \%$ lower than respective controls in 'P3167', '32K61', and 'Bora', respectively. The water deficit index was also adversely affected in all cultivars by salinity. It was found to be 2.75-2.80- and 2.2-fold higher than controls in 'P3167', '32K61', and 'Bora', respectively $(p<0.05)$ (Fig. 2b).

\subsection{PHOTOSYNTHETIC PIGMENT AND ANTHO- CYANIN}

According to the results, there was an inverse relationship between salt stress and photosynthetic pigment content. Chlorophyll a content, for example, significantly decreased by $30 \%, 42 \%$, and $22 \%$ in comparison with controls when salt stress was applied in the growth medium $(p<0.05)$ (Fig. 3a). Similarly, chlorophyll b content in the leaves of genotypes 'P3167' and '32K61' was $40 \%$ and $48 \%$ lower than respective controls and these changes were found to be statistically significant $(p<0.05)$. In the genotype 'Bora', however, chlorophyll b content was decreased by $15 \%$ in comparison with control and this change was not significant $(p>0.05)$ (Fig. 3b).

Salt treatment did not affect total anthocyanin content in the leaves of maize genotypes significantly $(p>$ 0.05) (Fig 3c). In the genotypes 'P3167' and '32K61' under salt stress, total anthocyanin content in the leaves were $60 \%$ and $129 \%$ higher than respective controls while salt stress decreased it by $24 \%$ in the leaves of 'Bora'.

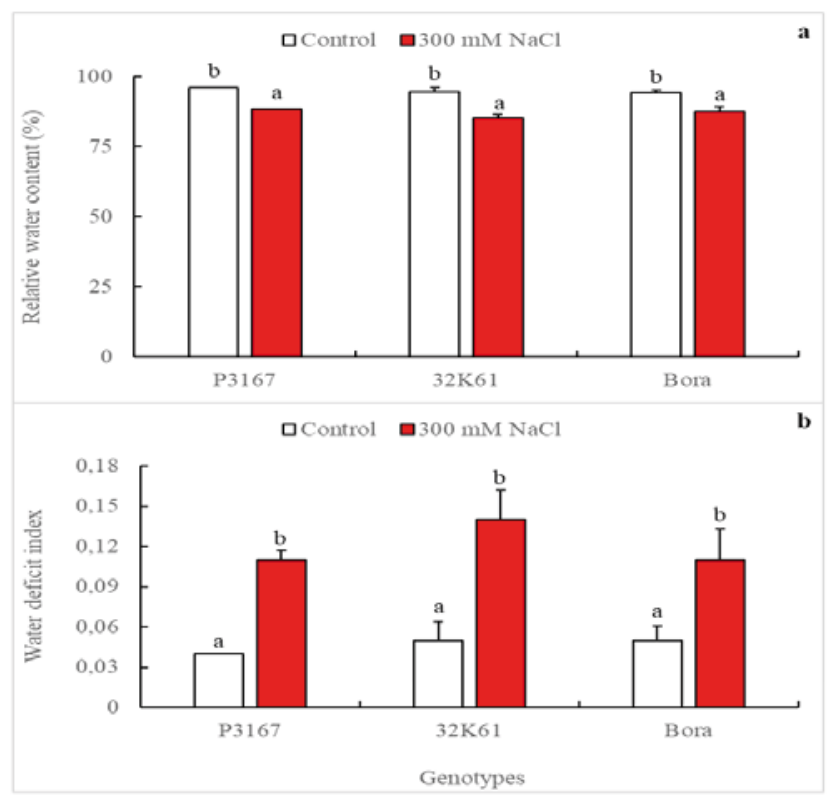

Figure 2: Effect of the salt stress on (a) relative water content and (b) water deficit index of maize plants (Different letters mean significant differences between the treatments according to Duncan's multiple range test $(p<0.05))$ 


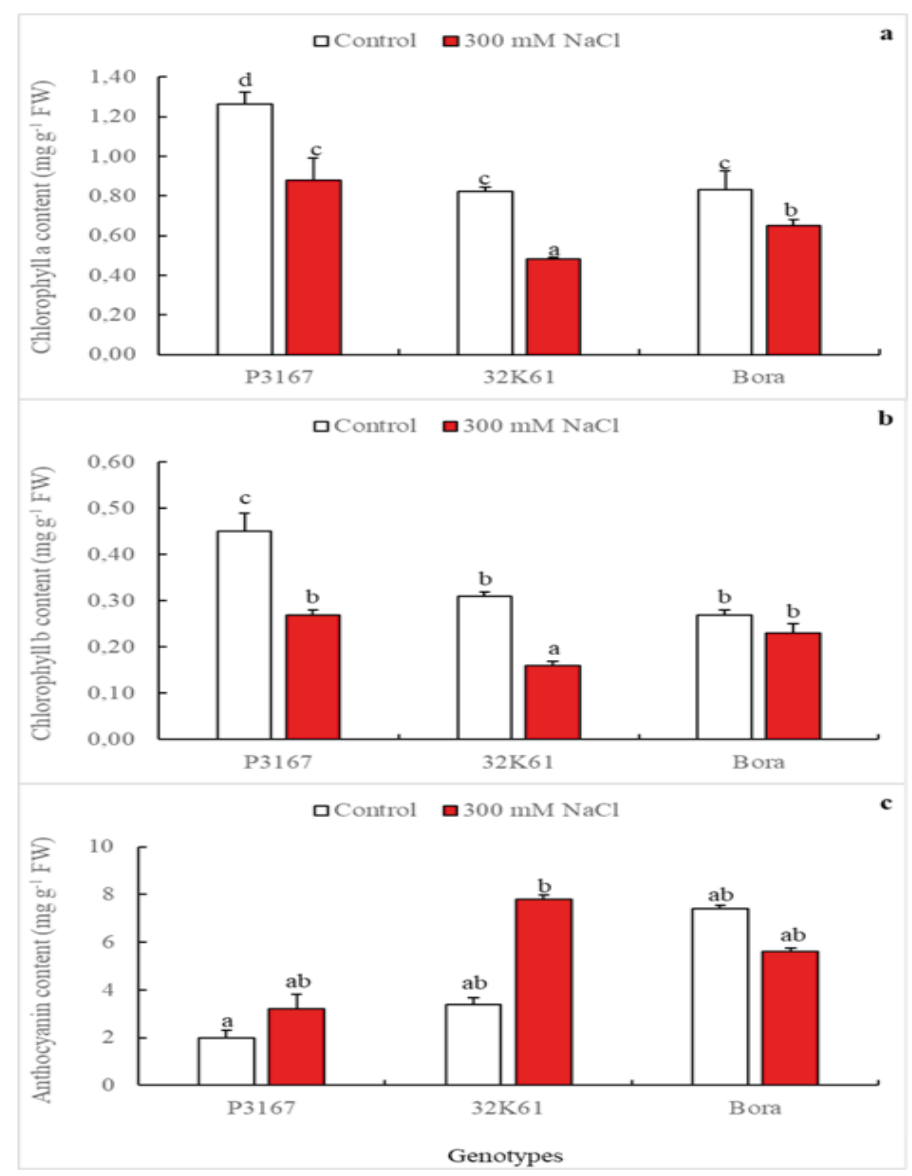

Figure 3: Effect of the salt stress on (a) chlorophyll a, (b) chlorophyll b and (c) anthocyanin content of maize plants (Different letters mean significant differences between the treatments according to Duncan's multiple range test $(p<0.05))$

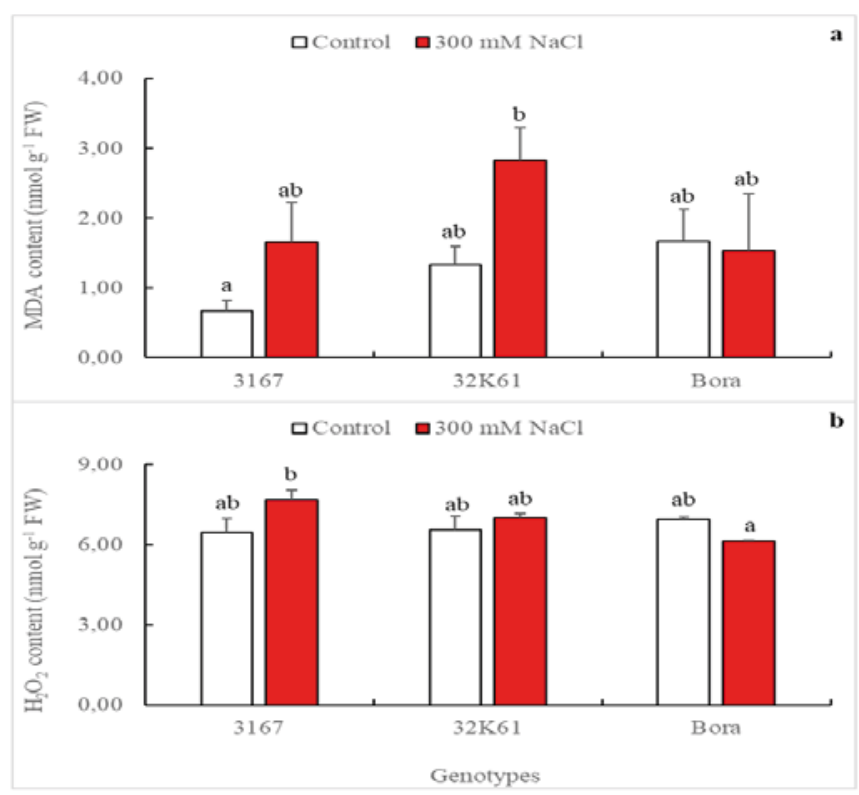

Figure 4: Effect of the salt stress on (a) MDA and (b) $\mathrm{H}_{2} \mathrm{O}_{2}$ content of maize plants (Different letters mean significant differences between the treatments according to Duncan's multiple range test $(p<0.05))$ 


\subsection{MALONDIALDEHYDE (MDA) AND HYDRO- GEN PEROXIDE $\left(\mathrm{H}_{2} \mathrm{O}_{2}\right)$}

The rate of MDA accumulation was $146 \%$ and $113 \%$ higher in the salt-stressed 'P3167' and '32K61' leaves while it was found to be $8 \%$ lower in the 'Bora' leaves as compared to control (Fig. 4a). However, these changes were not statistically significant $(p>0.05)$. Similarly, $\mathrm{H}_{2} \mathrm{O}_{2}$ content in the salt-stressed 'P3167' and '32K61' leaves represented insignificant increases, with $19 \%$ and $7 \%$ in comparison with respective controls, respectively. The $\mathrm{H}_{2} \mathrm{O}_{2}$ accumulation in the leaves of 'Bora' under salinity was $12 \%$ and insignificantly lower than control $(p>0.05)$.

\subsection{FREE PROLINE, TOTAL PHENOLIC, AND TOTAL SOLUBLE CARBOHYDRATE}

The rate of free proline accumulation was $13 \%$ and $22 \%$ higher in the salt-stressed 'P3167' and ' $32 \mathrm{~K} 61$ ' leaves while it was found to be $6 \%$ lower in the 'Bora' leaves as compared to control (Fig. 5a). However, these changes were not statistically significant $(P>0.05)$.

Phenolic content in the leaves of 'P3167' and '32K61' was induced by salinity (Fig. 5b) and it was significantly increased by $19 \%$ and $83 \%$, respectively $(p<0.05)$. In 'Bora', however, change in the phenolic content was not significant and it was increased by $10 \%$ under salt stress $(p>0.05)$.

Higher but insignificant amount of TSC content (54\% higher than control) was measured in the saltstressed leaves of 'P3167' ( $p>0.05$ ) (Fig. 5c). In the saltstressed leaves of ' $32 \mathrm{~K} 61$ ', however, TSC content was not significantly affected but it was $18 \%$ lower than the respective control. Salinity led to the significantly decreased TSC content ( $75 \%$ of the control) in the leaves of 'Bora' $(p<0.05)$.

\subsection{ANTIOXIDANT SYSTEM}

Salt stress remarkably increased the reduced ascor-

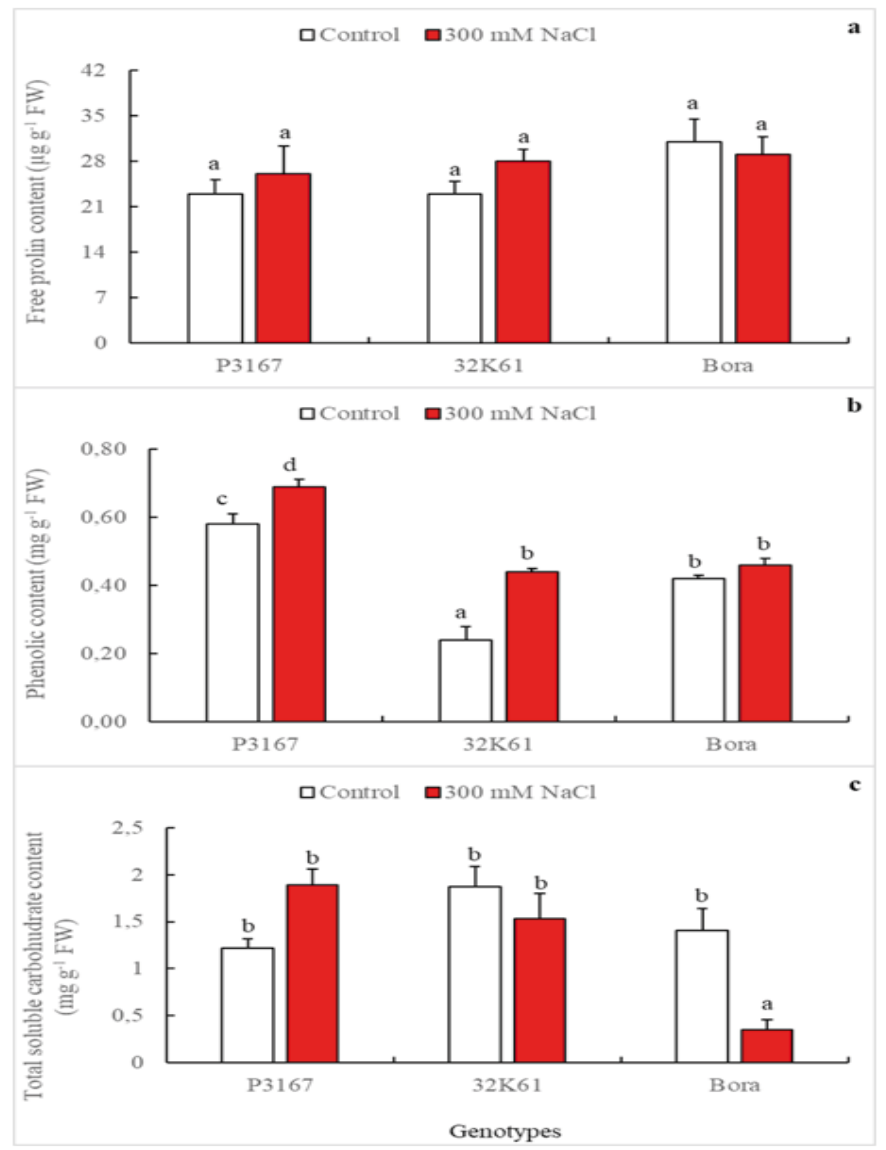

Figure 5: Effect of the salt stress on (a) free proline, (b) phenolic and (c) TSC content of maize plants (Different letters mean significant differences between the treatments according to Duncan's multiple range test $(p<0.05))$ 


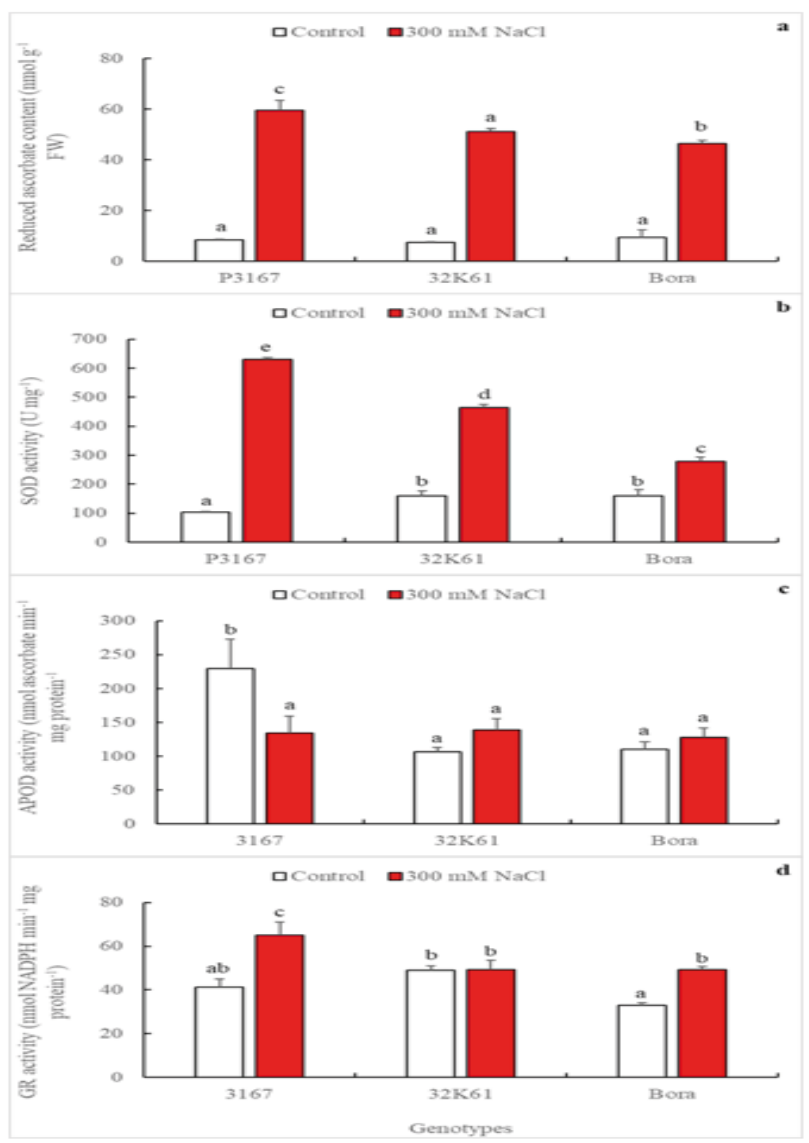

Figure 6: Effect of the salt stress on (a) the reduced ascorbate content, (b) SOD activity, (c) APOD activity and (d) GR activity of maize plants (Different letters mean significant differences between the treatments according to Duncan's multiple range test $(p<$ $0.05)$ )

bate content to 7-, 7- and 5-fold in 'P3167', '32K61', and 'Bora', respectively $(p<0.05)$ (Fig. 6a). Similarly, SOD activity was found to be significantly higher than respective controls in all maize genotypes under salt stress $(p<0.05)$ (Fig 6b). SOD activity was $506 \%, 191 \%$, and $75 \%$ higher than controls in 'P3167', '32K61', and 'Bora', respectively. APOD activity was significantly and $42 \%$ lower than the respective control in 'P3167' under salinity $(p<0.05)$ (Fig $6 c)$. In '32K61' and 'Bora', however, insignificant changes were determined in APOD activity as a result of salt stress $(p>0.05)$. It was $31 \%$ and $15 \%$ lower than controls (Fig. $6 c)$. In the case of GR activity, significantly higher values were measured in 'P3167' and 'Bora' (57 \% and $50 \%$, respectively) as compared to control $(p<0.05)$ while it was not affected and was only $1 \%$ higher than control in '32K61' under salinity stress ( $p>0.05)$ (Fig 6d).

\section{DISCUSSION}

Salt stress generally causes reduction in the growth rate in plants as result of the decreased ability of plants to take up water from the soil (Munns, 2002). It was reported that the growth ability of plants under salt stress maight be a reliable criterion to determine the salt tolerance degree of plants (Parida and Das, 2005). In the present study, root and shoot growth of all maize genotypes were negatively affected by salt stress $(300 \mathrm{mM}$ $\mathrm{NaCl}$ ). When genotypes were compared to each other, root growth in the genotypes 'P3167' and '32K61' was found to be more sensitive to salinity while 'Bora' was more tolerant. With regard to organ type, however, shoot growth was more sensitive to salinity in all maize genotypes. These results showed that the roots and shoots of maize genotypes used in this study showed considerable variation with respect to salinity tolerance. These results are also in agreement with the findings of Doğru and Yilmaz Kaçar (2019), who manifested that sensitivity and/or tolerance of different barley genotypes may represent great variation under saline conditions. It was also indicated that salt stress may interfere with mitotic activity in the meristematic cells in plants, depending on the 
plant species, genotype, organ type, and exposure time (Munns, 2002). Accordingly, we may conclude that the meristematic cells in the shoot apex are more sensitive to salinity as compared to the root meristems, probably due to more efficient transport of salt ions from roots to shoots, as reported by Zaimoğlu and Doğru (2016). Growth retardation in roots and shoots can be related to the inhibited cell elongation in plants under salt stress (Bendeoğlu et al., 2014). In the present study, it was observed that salt stress decreased RWC and increased water deficit index in the leaves of maize genotypes. Therefore, another possible reason for the reduced growth rate in maize genotypes under salt stress may be associated with the reduced RWC and induced water deficit index in the leaves. In addition, closure of the stomata and further disruption of the transpiration stream as result of water deficit-induced stimulation of abscisic acid synthesis may be indirectly responsible for the reduced growth rate in the salt-stressed maize genotypes used in this study (Polash et al., 2018).

The results of the present study indicated a significant decrease in chlorophyll a content in the salt-stressed maize genotypes which is in agreement with the previous studies of Turan et al. (2007) on Phaseolus vulgaris L. and Taffouo et al. (2010) on Vigna subterranean L. Chlorophyll b content was found to decrease only in 'P3167' and '32K61'. The decreased chlorophyll level can be attributed to the inhibition of chlorophyll biosynthesis and/or to the degradation by chlorophyllase (Santos, 2004). In addition, the results showed that chlorophyll $\mathrm{b}$ molecules were better preserved in the genotype 'Bora' under salt stress. In salt-stressed plants, the reduced chlorophyll content was considered as a typical symptom of oxidative stress (Smirnoff, 1996). On the other hand, the reduced chlorophyll content had been considered as a protective mechanism against oxidative stress as well (Elsheery and Cao, 2008). The results of the present study showed that salt stress did not cause oxidative stress in maize genotypes used in this study, as demonstrated by lower-level MDA and $\mathrm{H}_{2} \mathrm{O}_{2}$. Accordingly, total anthocyanin content did not represent considerable changes in the salt-stressed maize leaves. Anthocyanins are diverse group of secondary metabolites that could be produced in response to oxidative stress (Chunthaburee et al., 2016). Proline is a water-soluble amino acid and is involved in ROS detoxification (Ashraf and Foolad, 2007). In this study, salt stress did not induce free proline accumulation in the maize cultivars, confirming the hypothesis that maize genotypes are not under oxidative stress as result of salt application. An alternative explanation for this may be that oxidative stress on the maize genotypes under salt stress is eliminated by different defence mechanism as well. A possible defence mechanism that could eliminate oxida- tive stress on the salt-stressed maize genotypes may be the accumulation of phenolic compounds in leaf tissues. In this study, we observed that salt stress increased the phenolics in the leaves of 'P3167' and '32K61'. This result is in agreement with the previous reports on Aloe vera (L.) Burm.f. and radish (Moghbeli et al., 2012; Sakamoto and Suzuki, 2019). Phenolics are believed to prevent the formation of ROS under drought stress (Mayer and Harel, 1991). Parida et al. (2004) have also reported that increases in phenolic content in plant tissues ameliorate the ionic effects of salt stress. Therefore, the enhanced level of phenolic compounds in the leaves of 'P3167' and '32K61' under salt stress may be beneficial to achieve salt tolerance. Phenolic compounds have also been indicated to prevent lipid peroxidation and accumulation of MDA (Potapovich and Kostyuk, 2003), as reported in this study. In the present study, the level of the reduced ascorbate in the leaves of maize genotypes was increased by salinity as reported by several authors previously (Panda and Upadhyay, 2004; Chen et al., 2005). The reduced ascorbate is known to be a detoxifier or neutralizer of superoxide, $\mathrm{H}_{2} \mathrm{O}_{2}$, and singlet oxygen species. This result may explain the constant level of $\mathrm{H}_{2} \mathrm{O}_{2}$ content and APOD activity in the leaves of the salt-stressed maize genotypes used in this study. In other words, $\mathrm{H}_{2} \mathrm{O}_{2}$ accumulation in the salt-stressed leaves of the maize genotypes are prevented by the direct action of the reduced ascorbate instead of APOD activity. The elevated SOD activity in maize genotypes under salt stress may be an indicator of the accelerated rate of superoxide formation and detoxification (Doğru and Çakırlar, 2020a). GR activity increased in the salt-stressed leaves of the 'P3167' and 'Bora' while it did not change in ' $32 \mathrm{~K} 61$ '. These results could be interpreted as the lower activity of the ascorbate-glutathione cycle because of the absence of harmony between APOD and GR activities (Doğru and Çakırlar, 2020b). TSC content was not affected in the salt-stressed leaves of the 'P3167' and ' $32 \mathrm{~K} 61$ ' while it was decreased in the leaves of 'Bora'. It has been reported that soluble sugars play an important role in osmotic adjustment in plant cells under stressful conditions (Doğru and Ecem Bayram, 2016). According to the results in this study, it could be concluded that TSC is not involved in the osmotic regulation in the saltstressed 'P3167' and '32K61'. However, TSC may serve as carbon reserves in these genotypes. In the salt-stressed leaves of 'Bora', a lower level of TSC may show that they are used for growth and development.

In conclusion, the present study showed that salt stress reduced the growth rate in the salt-stressed maize genotypes, and shoot growth was more sensitive to salinity in comparison with root growth. In addition, salt stress led to the water deficit (physiological drought) in all genotypes, probably resulting in growth retardation. 
In 'P3167' and '32K61', salt stress predominantly and adversely affected chlorophyll a content while 'Bora' retained both chlorophylls a and b. The elevated SOD activity in all maize genotypes under salt stress may indicate an efficient dismutation of superoxide radical. Changes in APOD and GR activities under salinity clearly showed an increased pressure on the ascorbate-glutathione cycle, especially in 'P3167' and '32K61'. The constant level of $\mathrm{H}_{2} \mathrm{O}_{2}$ and MDA in the salt-stressed leaves of maize genotypes may show that the reduced ascorbate and phenolic compounds may be responsible for avoiding the adverse effects of oxidative stress. Finally, the genotype 'Bora' could be considered as having tolerance to salinity while 'P3167' and '32K61' are sensitive ones.

\section{ACKNOWLEDGMENT}

This study is supported by Sakarya University Scientific Research Projects Coordination Unit. Project Number: 2010-02-20-009.

\section{REFERENCES}

Abdelkader, M.A.I., Hassan, H.M.S., Elboraie, E.A.H. (2019). Using proline treatments to promote growth and productivity of Rosmarinus officinalis L. plant grown under soil salinity conditions. Middle East Journal of Applied Sciences, 9, 700-710.

Ahammed, G.J., Li, Y., Li, X., Han, W.Y., Chen, S. (2018). Epigallocatechin-3-gallate alleviated salinity-retarded seed germination and oxidative stress in tomato. Journal of Plant Growth Regulation, 37, 1349-1356. https://doi.org/10.1007/ s00344-018-9849-0

Asada, K. (2006). Production and scavenging of reactive oxygen species in chloroplasts and their functions. Plant Physiology, 141, 391-396. https://doi.org/10.1104/pp.106.082040

Ashraf, M., Foolad, M.R. (2007). Roles of glycine betaine and proline in improving plant abiotic stress tolerance. Environmental and Experimental Botany, 59, 206-216. https://doi. org/10.1016/j.envexpbot.2005.12.006

Bendeoğlu, E., Eyidoğan, F., Yücel, M., Öktem, H. A. (2014). Antioxidant responses of shoots and roots of lentil to $\mathrm{NaCl}-$ salinity stress. Plant Growth Regulation, 42, 69-77. https:// doi.org/10.1023/B:GROW.0000014891.35427.7b

Chandler, S. F., Dodds, J. H. (1983). The effect of phosphate, nitrogen and sucrose on the production of phenolics and socosidine in callus cultures of Solanum laciniatum. Plant Cell Reports, 2, 105-108.

Chen, Y., Zheng, H.L., Xio, Q., Huang, W.B., Zhu, Z. (2005). Effects of salinity on oxidative and antioxidative system of Spartina alterni flora. Xiamen Daxue Xuebao, 44, 576-579.

Chunthaburee, S., Sakuanrungsirikul, S., Wongwarat, T., Sanitchon, J., Pattanagul, W., Theerakulpisut, P. (2016). Changes in anthocyanin content and expression of anthocyanin syn- thesis gene in seedlings of black glutinous rice in response to salt stress. Asian Journal of Plant Science, 15, 56-65. https://doi.org/10.3923/ajps.2016.56.65

Doğru, A., Çakırlar, H. (2020a). Is leaf age a predictor for cold tolerance in winter oilseed rape plants? Functional Plant Biology, 47, 250-262. https://doi.org/10.1071/FP19200

Doğru, A., Çakırlar, H. (2020b). Effects of leaf age on chlorophyll fluorescence and antioxidant enzymes in winter rapeseeds leaves under cold acclimation conditions. Brazilian Journal of Botany, 43, 11-20. https://doi.org/10.1007/ s40415-020-00577-9

Doğru, A., Ecem Bayram, N. (2016). A study on drought stress tolerance in some maize (Zea mays L.) cultivars. SAU Journal of Science, 20, 509-519. https://doi.org/10.16984/ saufenbilder.25673

Doğru, A., Yılmaz Kaçar, M. (2019). A preliminary study on salt tolerance of some barley genotypes. SAU Journal of Science, 23, 755-762. https://doi.org/10.16984/saufenbilder.371055

Dubois, M., Gilles, K.A., Hamilton, K.J., Rebers, P.A., Smith, F. (1956). Colorimetric method for determination of sugars and related substances. Analytical Chemistry, 28, 350-356. https://doi.org/10.1021/ac60111a017

Elsheery, N.I., Cao, K.F. (2008). Gas exchange, chlorophyll fluorescence, and osmotic adjustment in two mango cultivars under drought stress. Acta Physiologiae Plantarum, 30, 769777. https://doi.org/10.1007/s11738-008-0179-x

Fayez, K.A., Bazaid, S.A. (2014). Improving drought and salinity tolerance in barley by application of salicylic acid and potassium nitrate. Journal of the Saudi Society of Agricultural Sciences, 13, 45-55. https://doi.org/10.1016/j.jssas.2013.01.001

Gapinska, M., Sklodowska, M., Gabara, B. (2008). Effect of short- and long-term salinity on the activities of the antioxidative enzymes and lipid peroxidation in tomato roots. Acta Physiologia Plantarum, 30, 11-18. https://doi. org/10.1007/s11738-007-0072-Z

Gu, R., Zhou, Y., Song, X., Xu, S., Zhang, X., Lin, H., Xu, S., Zhu, S. (2018). Effects of temperature and salinity on Ruppia sinensis seed germination, seedling establishment, and seedling growth. Marine Pollution Bulletin, 134, 177-185. https://doi.org/10.1016/j.marpolbul.2017.08.013

Hameed, A., Bibi, N., Akhter, J., Iqbal, N. (2011). Differential changes in antioxidants, proteases, and lipid peroxidation in flag leaves of wheat genotypes under different levels of water deficit. Plant Physiology and Biochemistry, 49, 178185. https://doi.org/10.1016/j.plaphy.2010.11.009

Hare, P.D., Cress, W.A., van Staden, J. (1998). Dissecting the roles of osmolyte accumulation during stress. Plant Cell and Environment, 21, 535-553. https://doi.org/10.1046/j.13653040.1998.00309.x

Hasan, M.K., Islam, M.S., Islam, M.R., Ismaan, H.N., El Sabagh, A., Barutçular, C., Meena, R.S., Saneoka, H. (2019). Water relations and dry matter accumulation of black gram and mung bean as affected by salinity. Thai Journal of Agricultural Science, 52, 54-67.

Khayamim, S., Afshari, R.T., Sadeghian, S.Y., Poustini, K., Rouzbeh, F., Abbasi, Z. (2014). Seed germination, plant establishment, and yield of sugar beet genotypes under salin- 
ity stress. Journal of Agricultural Science and Technology, 16, 779-790.

Law, M.Y., Charles, S.A., Halliwell, B. (1983). Glutathione and ascorbic acid in spinach (Spinacia oleracea) chloroplasts. Biochemical Journal, 210, 899-903. https://doi.org/10.1042/ bj2100899

Mancinelli, A.L., Yang, C.P.H., Lindquist, P., Anderson, O. R., Rabino, I. (1975). Photocontrol of anthocyanin synthesis III. The action of streptomycin on the synthesis of chlorophyll and anthocyanin. Plant Physiology, 55, 251-257. https://doi.org/10.1104/pp.55.2.251

Mayer, A.M., Harel, E. (1991). Phenol oxidases and their significance in fruit and vegetables. Food Enzyme, 32, 373-398

Mittler, R. (2002). Oxidative stress, antioxidants and stress tolerance. Trends in Plant Science, 7, 405-410. https://doi. org/10.1016/S1360-1385(02)02312-9

Moghbeli, E., Fathollahi, S., Salari, H., Ahmadi, G., Saliqehdar, F., Safari, A., Grouh, M.S.H. (2012). Effects of salinity stress on growth and yield of Aloe vera L. Journal of Medicinal Plants Research, 6, 3272-3277. https://doi.org/10.5897/ JMPR11.1698

Munns, R. (2002). Comparative physiology of salt and water stress. Plant Cell and Environment, 33, 453-467. https://doi. org/10.1046/j.0016-8025.2001.00808.x

Munns, R., Tester, M. (2008). Mechanisms of salinity tolerance. Annual Review of Plant Biology, 59, 651-681. https://doi. org/10.1146/annurev.arplant.59.032607.092911

Orlovsky, N., Japakova, U., Zhang, H., Volis, S. (2016). Effect of salinity on seed germination, growth and ion content in dimorphic seeds of Salicornia europea L. (Chenopodiaceae). Plant Diversity, 38, 183-189. https://doi.org/10.1016/j. pld.2016.06.005

Panda, S.K., Upadhyay, R.K. (2004). The salt stress injury induces in the roots of Lemna minor. Biologia Plantarum, 48, 249 253. https://doi.org/10.1023/B:BIOP.0000033452.11971.fc

Parida, A.K., Das, A.B. (2005). Salt tolerance and salinity effects on plants: a review. Ecotoxicology and Environmental Safety, 60, 324-349. https://doi.org/10.1016/j.ecoenv.2004.06.010

Parida, A.K., Das, A.B., Sanada, Y., Mohanty, Y. (2004). Effects of salinity on biochemical components of the mangrove, Aegiceras corniculatum. Aquatic Botany, 80, 77-87. https:// doi.org/10.1016/j.aquabot.2004.07.005

Petridis, A., Therios, I., Samouris G., Tananaki, C. (2012). Salinity-induced changes in phenolic compounds in leaves and roots of four olive (Olea europaea L.) cultivars and their relationship to antioxidant activity. Environmental and Experimental Botany, 79, 37-43. https://doi.org/10.1016/j.envexpbot.2012.01.007

Polash, M.A.S., Sakil, M. A., Arif, T., Hossain, M. A. (2018). Effect of salinity on osmolytes and relative water content of selected rice genotypes. Tropical Plant Research, 5, 227 232. https://doi.org/10.22271/tpr.2018.v5.i2.029

Potapovich, A.I., Kostyuk, V.A. (2003). Comparative study of antioxidant properties and cytoprotective activity of flavonoids. Biochemistry, 68, 514-519. https://doi. org/10.1023/A:1023947424341

Sairam, R.K., Rao, K.V., Srivastava, G.C. (2002). Differential response of wheat genotypes to long-term salinity stress relation to oxidative stress, antioxidant activity and osmolyte concentration. Plant Science, 163, 1037-1046. https://doi. org/10.1016/S0168-9452(02)00278-9

Sairam, R.K., Tyagi, A. (2004). Physiology and molecular biology of salinity stress tolerance in plants. Current Science, 86, 407-421.

Sakamoto, M., Suzuki, T. (2019). Methyl jasmonate and salinity increase anthocyanin accumulation in radish sprouts. Horticulturae, 5, 62-75. https://doi.org/10.3390/horticulturae 5030062

Santos, C.V. (2004). Regulation of chlorophyll biosynthesis and degradation by salt stress in sunflower leaves. Scientia Horticulturae, 103, 93-99. https://doi.org/10.1016/j.scienta.2004.04.009

Smirnoff, N. (1996). Botanical briefing: the function and metabolism of ascorbic acid in plants. Annals of Botany, 78, 661-669. https://doi.org/10.1006/anbo.1996.0175

Taffouo, V.D., Wamba, O.F., Yombi, E., Nono, G.V., Akoa, A. (2010). Growth, yield, water status and ionic distribution response of three Bambara groundnut (Vigna subterranean (L.) verdc.) landraces grown under saline conditions. International Journal of Botany, 6, 53-58. https://doi. org/10.3923/ijb.2010.53.58

Turan, M.A., Türkmen, N., Taban, N. (2010). Effect of $\mathrm{NaCl}$ on stomatal resistance and proline, chlorophyll, $\mathrm{NaCl}$ and $\mathrm{K}$ concentrations of lentil plants. Journal of Agronomy, 6, 378381. https://doi.org/10.3923/ja.2007.378.381

Wijayasinghe, M.M., Jayasuriya, K.M.G.G., Gunatilleke, C.V.S., Gunatilleke, I.A.U.N., Walck, J.L. (2019). Effect of salinity on seed germination of five mangroves from Sri Lanka: use of hydrotime modelling for mangrove germination. Seed Science Research, 29, 55-63. https://doi.org/10.1017/ S0960258518000405

Yıldırım, E., Turan, M., Güvenç, İ. (2008). Effect of foliar salicylic acid applications on growth, chlorophyll, and mineral content of cucumber grown under salt stress. Journal of Plant Nutrition, 31, 593-612. https://doi. org/10.1080/01904160801895118

Zaimoğlu, S., Doğru, A., Farklı mısır genotiplerinde tuz stresinin bazı büyüme parametreleri ve fotosentetik aktivite üzerindeki etkileri. 23. Ulusal Biyoloji Kongresi pp. 270, 2016. 